\title{
Students' Reasoning and Fallacies in Indonesian EFL Classroom
}

\author{
Delpani Selpia, Sri Setyarini \\ English Education Department, School of Postgraduate Studies \\ Universitas Pendidikan Indonesia \\ Bandung, Indonesia \\ delpaniselpia@upi.edu
}

\begin{abstract}
This study is about 30 students' ways of logic and reasoning in English language learning analyzed through HOTSbased questions in a private senior high school context in West Sumatera, Indonesia. All students were in the first grade who just began their first semester in the school. First, class observation was done. A field note was used to write down the process of teaching and learning a descriptive text during the observation done in two meetings. It was found that the teacher explained some easy reading and answering skills related to reasoning skills during the two meetings. Then, students' worksheets were collected to be later analyzed. Next, a stimulated recall interview was conducted to investigate students' responses toward their reading and answering techniques as well as their difficulties in reasoning. To increase the reliability of the students' categorization of reasoning and fallacies, I was helped by an interrater who works as a lecturer in a Public University whose research interest is also on HOTS. The findings showed that about two-thirds of all students' answers in this study contained poor reasoning and fallacious statements meaning that they had not been able to have HOTS in understanding the descriptive text given. The findings also revealed that students' understanding of vocabulary and good comprehension of the overall text determined students' thinking ability.
\end{abstract}

\section{Keywords: fallacies, HOT, HOTS, logic, reasoning}

\section{INTRODUCTION}

Higher Order Thinkin Skill or HOTS is one of the main concerns in the field of education in the 21 st century since it is an important tool for filtering, absorbing, sorting, and surviving in the world without borders where information is scattered and can come anytime and anywhere (Lee, 2014; Vijayaratnam, 2012; Yen \& Halili, 2015; Zohar \& Cohen, 2016). Because of its increasing role, HOTS in teaching English has also begun to be discussed by several scholars of education and teaching (Anderson \& Krathwohl, 2000; Atkinson, 1997; Brookhart, 2010; El Khoiri \& Widiati, 2017; Li, 2016; Mayfield, 2007; Osman \& Kassim, 2015; Stapleton, 2001). In general, the specifications of their research are on how HOTS can be assessed on all four English skills.

HOTS-based learning is very much in line with the goals of 21 st-century education, which is to make students able to hone critical thinking skills, to understand what they are doing, and justify them on the right reasons (Gardner, 1999; Zohar \& Cohen, 2016). Then, the National Council of Teachers of English in 2005 stated that students need to be taught to be critical users of language, which is a part of HOTS, crossing cultural boundaries. Besides, it can be found in the philosophical foundation of education in this current curriculum that the categories of HOTS demanded here involve students' problem-solving skills, critical thinking skills, creative thinking skills, and reasoning skills.

Brookhart (2010) then explained the benefits obtained if students understand the correct logic that is an increase in their academics. Awareness of reasoning and fallacy is needed for students to avoid making mistakes and aware of the power of arguments from someone (El Khoiri \& Widiati, 2017). Then, Mayfield (2014) said that there are at least 3 advantages if students understand logical fallacies. First, they will learn about correct logic; second, they will try not to use wrong logic; and third, they will not be affected by arguments containing fallacies. Thus, it can be seen from the goals of $21^{\text {st }}$ century learning above that one of the elements that is worth investigating as an element of building higher-order thinking skills is students' reasoning and logical fallacies. Brookhart (2010) mentioned that reasoning skills are important to teach since students are young-they don't have to be mature to start producing strong, precise and true arguments.

Various studies have reported research regarding students' reasoning and logical fallacies. Atai and Nasseri (2010) studied whether informal fallacies of argumentation in Iranian EFL students are influenced by other variables. The result was that gender, age, and discipline did not significantly affect students' writing skills in this context. The result of a study done by Yang and Gao (2013) in a university in China revealed that logical issues were the major problems in student writing. In the Indonesian context, El Khoiri and Widiati (2017) analyzed 40 argumentative essays of students in English major in a public university in Indonesia. The analysis shows that students still produced many logical fallacies in their work. Some of them could be avoided since the mistakes on logical fallacies are very preventable and easy to be understood through simple and explicit instruction. Then, Indah and Kusuma (2015) studied fallacious statements of students in another public university in Indonesia and found several types of fallacies there, namely ad populum, appeal to emotion premises, red herrings, hasty generalization, and many other types. This statement reveals that students in higher education contexts still have many types of fallacies in their arguments.

Some experts classify fallacies and give examples of sentences containing fallacies in each of their types, one of which is Mayfield (2014). Mayfield's framework has been 
widely used by researchers in their research, especially in the context of learning in the higher education context. Instead, this study used a fallacy type framework from Brookhart (2010) that was specifically classified for younger students according to the specifications of this study, as shown in Table I.

TABLE I. BOOKHART'S FALLACY TYPE FRAMEWORK

\begin{tabular}{|c|c|c|}
\hline $\begin{array}{l}\text { Logical Error and } \\
\text { Definition }\end{array}$ & $\begin{array}{l}\text { Example of Poor } \\
\text { Reasoning }\end{array}$ & $\begin{array}{l}\text { Example of Good } \\
\text { Reasoning }\end{array}$ \\
\hline $\begin{array}{l}\text { Overgeneralizing } \\
\text { Reasoning from one or a } \\
\text { very few examples to a } \\
\text { whole group. }\end{array}$ & $\begin{array}{l}\text { Billy and DeShaun } \\
\text { are bullies. They push } \\
\text { other kids around and } \\
\text { take things from } \\
\text { them. It must be } \\
\text { because they're boys. } \\
\text { I'm going to stay } \\
\text { away from all the } \\
\text { boys on the } \\
\text { playground. }\end{array}$ & $\begin{array}{l}\text { Billy and DeShaun } \\
\text { are bullies. They push } \\
\text { other kids around and } \\
\text { take things from } \\
\text { them. I'm going to } \\
\text { stay away from Billy } \\
\text { and DeShaun on the } \\
\text { playground. }\end{array}$ \\
\hline $\begin{array}{l}\text { Appeal to Authority } \\
\text { Reasoning that because } \\
\text { an important figure } \\
\text { believes or does } \\
\text { something, it is true, } \\
\text { good, or important. }\end{array}$ & $\begin{array}{l}\text { A famous movie star } \\
\text { says I should smoke } \\
\text { this brand of } \\
\text { cigarettes. He's cool, } \\
\text { so smoking these } \\
\text { cigarettes must be } \\
\text { cool, too. }\end{array}$ & $\begin{array}{l}\text { My doctor says I } \\
\text { shouldn't smoke } \\
\text { cigarettes. He has } \\
\text { read studies that show } \\
\text { smoking causes } \\
\text { cancer, and he doesn't } \\
\text { want me to get cancer. }\end{array}$ \\
\hline $\begin{array}{l}\text { Social Acceptability (In } \\
\text { Latin, ad populum } \\
\text { argument, sometimes } \\
\text { called the "bandwagon } \\
\text { argument") } \\
\text { Reasoning that } \\
\text { something is true because } \\
\text { lots of people believe it } \\
\text { or that something is good } \\
\text { because lots of people do } \\
\text { it. }\end{array}$ & $\begin{array}{l}\text { All my friends tell me } \\
\text { American Idol is the } \\
\text { best TV show to } \\
\text { watch. I should watch } \\
\text { it. I'll love it. }\end{array}$ & $\begin{array}{l}\text { I really like watching } \\
\text { American Idol } \\
\text { because I like music } \\
\text { and comedy. I also } \\
\text { like trying to guess } \\
\text { who the audience will } \\
\text { like and what the } \\
\text { judges will say. }\end{array}$ \\
\hline $\begin{array}{l}\text { Against the Person (In } \\
\text { Latin, ad hominem } \\
\text { argument) }\end{array}$ & $\begin{array}{l}\text { Lisa says that the } \\
\text { animal shelter is a } \\
\text { great place to } \\
\text { volunteer. But Lisa is } \\
\text { such a freak. She } \\
\text { wears such funny } \\
\text { clothes and is such a } \\
\text { loner. She's probably } \\
\text { wrong, and I } \\
\text { wouldn't like it. }\end{array}$ & $\begin{array}{l}\text { Lisa says that the } \\
\text { animal shelter is a } \\
\text { great place to } \\
\text { volunteer. I like } \\
\text { animals, so I might try } \\
\text { volunteering and see } \\
\text { if I like it }\end{array}$ \\
\hline $\begin{array}{l}\text { Straw Man } \\
\text { Reasoning by setting up a } \\
\text { simple-minded or } \\
\text { watered-down version of } \\
\text { your opponent's } \\
\text { argument, knocking it } \\
\text { down easily, and then } \\
\text { claiming your side of the } \\
\text { argument is therefore } \\
\text { right. }\end{array}$ & $\begin{array}{l}\text { My parents give me } \\
\text { an allowance, but } \\
\text { they only want me to } \\
\text { spend it on things I } \\
\text { need and save the } \\
\text { rest. That's dumb- } \\
\text { then why give me an } \\
\text { allowance? I should } \\
\text { be able to spend it on } \\
\text { anything I want. }\end{array}$ & $\begin{array}{l}\text { My parents give me } \\
\text { an allowance, but they } \\
\text { want me to think } \\
\text { carefully about the } \\
\text { things I spend money } \\
\text { on, and save some, } \\
\text { too. But I think I } \\
\text { should be able to } \\
\text { spend my allowance } \\
\text { on anything I want, } \\
\text { because once they } \\
\text { give it to me, it's my } \\
\text { money. }\end{array}$ \\
\hline
\end{tabular}

Most of the research so far, as seen in the previous paragraph, has studied how reasoning and fallacies have been analyzed in adult students' argumentative writings. Bearing in mind that reasoning skills can be developed and assessed in school since young age, as suggested by Brookhart (2010), the objective of this study is to investigate 30 senior high school students' ways of logic and reasoning in English language learning which would depict their higher-order thinking skills analyzed through HOTS-based questions under a topic of descriptive text in a private senior high school context in West Sumatra, Indonesia.

\section{METHOD}

This research is a qualitative research that reveals how students in this study make logic and fallacies on the topic of descriptive text lesson. 30 students who were joined in a class (23 girls and 7 boys) agreed to be participants in this study. All students were in the first grade who just began their first semester in the school. The sample is considered adequate for the chosen purposive sampling method as the possible pool of participants is already restricted (Marshall, 1996). The instruments used in this study were document (students' worksheets), stimulated recall interviews, and classroom observation using a field note. First, the English teacher and I constructed a new descriptive text entitled Borobudur Temple followed by 5 questions to present HOT elements in the text and in the questions. The questions consist of 2 multiple choices asking students to make correct conclusion based on the situation given in the text, and 3 questions asking students to construct their own arguments for the premises given in the questions. Then, I did a class observation using a field note to write down the process of teaching and learning the descriptive text in that class during the two meetings. I found that the teacher, in fact, without my invention, explained some easy reading and answering strategies related to reasoning skills and ways of avoiding logical fallacies during the two meetings. Then, the descriptive text and the questions were distributed to every participant in this study. They were given time for about 30 minutes to read and answer the questions on the same sheet. Finally, a stimulated recall interview was conducted to investigate students' strategies and difficulties dealing with the text and the questions. The interview was conducted in Indonesian so students can express their ideas and feelings freely. Then, I collected these students' worksheets to be then analyzed and categorized with the help of an inter-rater who is working as a lecturer with interest in also on HOTS. Since the questions given to students asked them to construct their arguments based on the situation and premises already given in the text, or in other words, gave them some things to reason about, their fallacies can be identified. These students' answers were then grouped according to Brookhart's framework (2010) to see whether they contain fallacies and whether they belong to good reasoning or poor reasoning as explained in the introduction part above.

\section{FINDINGS AND DISCUSSION}

\section{A. Findings}

The HOTS-based descriptive text distributed to students is a text containing 4 short paragraphs with the title Borobudur Temple. This text is then followed by 5 HOTS-based questions in the form of 2 multiple choices and 3 other questions requiring students to construct their arguments and make their conclusions based on a given situation. These questions require students to be able to think about things outside the text which are then able to show their HOTS. Below is the excerpt of the first three paragraphs of the text given to students as an attempt to identify their HOTS. 


\section{Borobudur Temple}

Borobudur temple is one of the most beautiful tourist resorts in Indonesia. It is situated in central Java. Borobudur temple is one of the Seven Wonders of the World in which its existence needs to be preserved. The people all over the world know that Borobudur is one of the greatest art works that ever known since long time ago. So, many people like to visit Borobudur temple during their holiday.

Borobudur temple was built by Syailendra Dynasty during the eight century. It needed more than two billion river stones. It is the biggest temple in the world.

After going into some restorations. Borobudur is visited by more and more tourists, both domestic and foreign tourists. Most of them admire Borobudur temple because of story of the relief on its walls. Borobudur temple always has many visitors every weekends and every red calendars. However, not really many people visit Borobudur temple during rainy season.

Domestic tourists usually go there by bus or private cars, while foreign tourists like to join travel bureau because they don't need to think of the transportation, accommodation, and itinerary.

Fig. 1. Text excerpt

As can be seen in Figure 1, the information contained in the text is indeed in the forms of facts also containing some premises and situation to see how well the participants in this study can construct their arguments based on the premises and situation contained in the text. Then, too see how the questions were meant to dig students' reasoning, I provide question 1, question 2, and question 4 Figure 2.

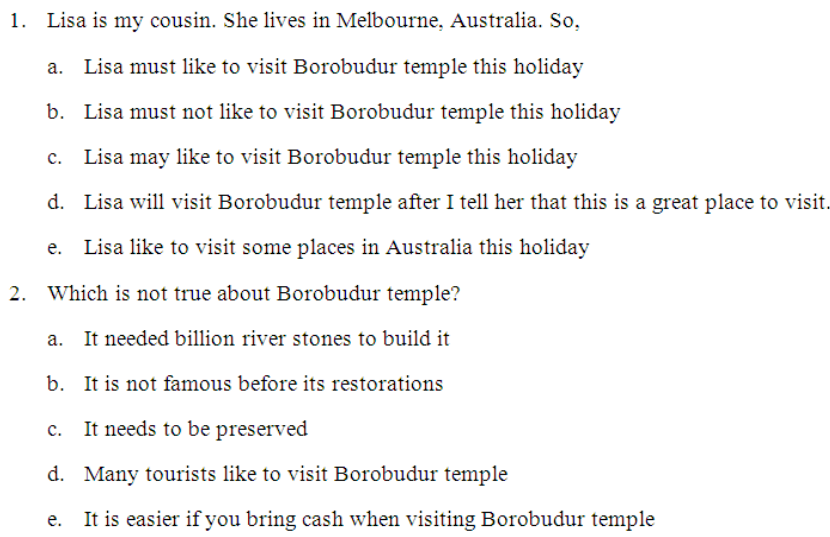

3. Some people from Russia visit Borobudur temple. They want to buy some souvenirs but they only have checks with them. What will they probably do?

\section{Fig. 2. Questions exceprt}

Then, after the students' answers were analyzed, the findings from this research are depicted in Table II. Based on the analysis of students' answers from HOTS- based descriptive text and questions, as depicted in the table above, it can be seen that 19 of students' answers in question number 1 contained a type of fallacies namely overgeneralizing. 23 of students' answers were categorized as fallacy of social acceptability in question number 2. Then, for question number 3, 1 type of fallacies namely against the person was found from two answers of the students. When working with these data, I was a bit surprised because I found one more type of fallacies which I put as not classified category. I have a guess here that few of the students' fallacies answers couldnot be categorized because of unclear statements, the use of unconnected English vocabulary, and unclear words where the meaning of the whole sentence couldnot be obtained. Question number 3 and number 5 were categories as not classified answers.

TABLE II. STUDENTS' REASONING AS SHOWN IN THEIR ANSWERS

\begin{tabular}{|c|c|c|c|c|c|c|c|c|}
\hline $\begin{array}{l}\text { n } \\
\text { o }\end{array}$ & $\begin{array}{c}\text { Reasoni } \\
\text { ng } \\
\text { ability }\end{array}$ & fallacies & $\begin{array}{l}\mathbf{Q} \\
\mathbf{1}\end{array}$ & $\begin{array}{l}\mathbf{Q} \\
\mathbf{2}\end{array}$ & $\begin{array}{l}\mathbf{Q} \\
\mathbf{3}\end{array}$ & $\begin{array}{l}Q \\
4\end{array}$ & $\begin{array}{l}\mathbf{Q} \\
5\end{array}$ & Meaning \\
\hline \multirow[t]{6}{*}{1} & \multirow[t]{6}{*}{$\begin{array}{c}\text { Poor } \\
\text { reasonin } \\
\mathrm{g}\end{array}$} & $\begin{array}{c}\text { overgeneralizi } \\
\text { ng }\end{array}$ & $\begin{array}{l}19 \\
\text { ss }\end{array}$ & & & & & \multirow[t]{6}{*}{$\begin{array}{l}67 \text { ANSWERS } \\
\text { CONTAINED } \\
\text { FALLACIES }\end{array}$} \\
\hline & & $\begin{array}{l}\text { Appeal to } \\
\text { authority }\end{array}$ & & & & & & \\
\hline & & $\begin{array}{c}\text { Social } \\
\text { acceptability }\end{array}$ & & $\begin{array}{l}23 \\
\text { ss }\end{array}$ & & & & \\
\hline & & $\begin{array}{l}\text { Against the } \\
\text { person }\end{array}$ & & & $\begin{array}{c}2 \\
\text { ss }\end{array}$ & & & \\
\hline & & Straw man & & & & & & \\
\hline & & Not classified & & & $\begin{array}{l}7 \\
\text { ss }\end{array}$ & & $\begin{array}{l}16 \\
\text { ss }\end{array}$ & \\
\hline 2 & $\begin{array}{l}\text { Good } \\
\text { reasonin } \\
\mathrm{g}\end{array}$ & & $\begin{array}{l}11 \\
\text { ss }\end{array}$ & $\begin{array}{c}7 \\
\text { ss }\end{array}$ & $\begin{array}{l}21 \\
\text { ss }\end{array}$ & $\begin{array}{l}30 \\
\text { ss }\end{array}$ & $\begin{array}{l}14 \\
\text { ss }\end{array}$ & $\begin{array}{c}83 \text { ANSWERS } \\
\text { WERE } \\
\text { CATEGORIZ } \\
\text { ED AS GOOD } \\
\text { REASONING }\end{array}$ \\
\hline
\end{tabular}

Meanwhile, 11 other students had good reasoning in question number 1.7 of students' answer for question number 2 were categorized as good reasoning. 21 students had good reasoning in answering question number 3. A greater number, that is 30 students, had good reasoning in answering question number 4. Meanwhile, 14 of students' answers in question number 5 had also been classified as good reasoning because they did not contain any type of fallacy.

A stimulated recall interview was conducted to reflect what students meant in their answers, to gain students' reasons for choosing those selected and written answers, and to dig students' ideas on HOTS based text and questions. A stimulated recall interview was done directly after the answers answered the questions.

The result of students 'answers analysis using Brookhart framework (2010) shows that students' answers were categorized in both kinds of reasoning; good reasoning and poor reasoning. The five types of poor reasoning or fallacies were found in all students' answers namely overgeneralizing, appeal to authority, against the person, straw man, and social acceptability. As seen in Table II, 19 of students' answers were categorized as overgeneralizing for question number 1 which was a multiple choice one. In this question, students had to choose one new correct conclusion from the 5 answers provided. The example of the same case was already provided in the text. From the results of the stimulated recall interview, many opinions were obtained from students. Some students did have HOTS so they could answer correctly, some students did not have HOTS so that they could not conclude the situation in this question, and some students had not been able to distinguish the correct use of modalities as required by question no. 1 so they answered it wrong. 
23 students did not have good reasoning in answering question no 2 which was also in the form of multiple-choice from option A to E. These fallacies were categorized as social acceptability where the question demanded students to choose one incorrect statement based on the information in the reading. After being interviewed, these students had different answers but were almost similar to the ideas in question number 1 . Some of them said that they were not careful in locating specific information about the question in the text so they concluded it wrong. Some other students admitted that they were even shocked knowing that this kind of question is tricky and very critical. Only a few of them had good reasoning so they answered it correctly.

For question number 3, one type of fallacies was identified namely against the person. As it was only two students who had poor reasoning in answering questions number 3 , it was concluded that most students had no problems in answering this type of questions where they were asked to guess what characters from the text would do if given a situation as stated in the question. The students were free to sound their reasoning. When I was working with this analysis, I also found 7 students who were answered were categorized as not classified competing that their answers could not be categorized into many types of fallacies because they contained ambiguity and unclear and inappropriate vocabulary which influenced the meaning of their sentences.

Then, it was nice that students did not make any fallacies in answering question number 4 which had the same format as in question number 3 . It can be said that all students had good reasoning in the type of question where they were asked to state the reason for making a certain decision freely based on an assumption described in the text. As for question number 5, 16 students had poor reasoning while 14 others' reasoning was categorized good. The question number five is a question of ifso logic like ones often found in mathematical cases. The students were given two premises based on the information in the text, then they were asked to conclude it correctly. The interview transcription informs that students' answers were based on some reasons. Some stated that they were confused about answering such high level of questions in the English lesson. Some others said that they were not accustomed and never taught about difficult with questions like those found this time. Luckily, some of them did have good reasoning in stating their arguments.

\section{CONCLUSIONS}

As outlined in the findings, for question number 1 which is in the form of multiple choice, more than half of students were categorized as having overgeneralizing which means that more than half of the students have poor reasoning depicting that they do not have Higher Order Thinking Skill or HOTS yet. For question number 2 which is also in the form of multiple choice, most of the students' answers were classified as social acceptability. This result shows that these students still have poor reasoning so that they do not have HOTS. Few students' answers were categorized as poor reasoning in question number 3 as they contained a type of fallacy namely against the person and some answers did not belong to any type of fallacies. All students have good reasoning and are categorized as having
HOTS in question number 4 that is constructing a conclusion. Meanwhile, half of the students' answers could not be classified for question number 5 because of unclear ideas, inappropriate vocabulary, and vocabulary limitation that made me and the teacher confused when analyzing the data. To sum up, most of the students in this research do not have Higher Order Thinking Skill or HOTS in answering HOT-based descriptive text questions in the form of multiple choices, constructing arguments, and constructing conclusions from premises provided.

The results of this research depict that students' reasoning in lower education contexts, as imported as reasoning skills in higher education contexts, needs to be taken into account. The students' thinking ability must be sharpened since they are young in the school time to minimize fallacious arguments in facing the challenges in this era where all kinds of information can be accessed in this $21^{\text {st }}$ century. It is very expected for the English teachers, in this context, to teach Higher Order Thinking Skill or HOTS simply and explicitly to achieve the $21^{\text {st }}$ century learning goal. After all, it is realized that this research has its limitation especially in the number of text given which should be more than one kind of text to obtain richer data.

\section{REFERENCES}

Anderson, L. W., \& Krathwohl, D. R. (2000). A taxonomy for learning, teaching, and assessing: A revision of Bloom's taxonomy of educational objectives. New York: Longman.

Atai, M. R., \& Nasseri, M. (2010). A gender-based study of informal fallacies of argumentation: The case of Iranian advanced EFL learners' writing. Indonesian Journal of Applied Linguistics, 13(2), 19-45.

Atkinson. (1997). A critical approach to critical thinking in TESOL. TESOL Quarterly, 31(1), 71-94

Brookhart, S. M. (2010). How to assess high order thinking skills in your classroom. Alexandria, VA: ASCD Member Book.

Gardner, H. (1999). Intelligence reframed: Multiple intelligences for the 21 st century. New York: Basic Books.

Indah, R. N., \& Kusuma, A. W. (2015). Fallacies in English Department students' claims: A rhetorical analysis of critical thinking. Jurnal Pendidikan Humaniora, 3(4), 295-304.

El Khoiri, N., \& Widiati, U. (2017). Logical fallacies in EFL learners' argumentative writings. Dinamika Ilmu, 17(1), 71-81. doi: 10.21093/di.v17i1.638

Lee, S. M. (2014). The relationship between higher order thinking skills, cognitive density, and social presence in online learning. The Internet and Higher Education, 21, 41-52. doi: 10.1016/j.iheduc.2013.12.002

Li, L. (2016). Integrating thinking skills in foreign language learning: What can we learn from teacher's perspectives? Thinking Skills and Creativity, 22, 273-288. doi: 10.1016/j.tsc.2016.09.008

Marshall, M. N. (1996). Sampling for qualitative research. Family Practice, 13(6), 522-526. doi: 10.1093/fampra/13.6.522

Mayfield, M. (2007). Thinking for yourself: Developing critical thinking skills through reading and writing $\left(7^{\text {th }}\right.$ Edn.). Boston, MA: Thomson Wadsworth.

Mayfield, M. (2014). Thinking for yourself: Developing critical thinking skills through reading and writing ( $9^{\text {th }}$ Edn.). Boston, MA: Wadsworth, Cengage Learning.

National Council of Teachers of English. (2005). Principles of supporting linguistically and culturally diverse English learners in the 21 stcentury. Retrieved from http://www2.ncte.org/statement/diverselearnersinee. 
Osman, N., \& Kassim, H. (2015). Exploring strategic thinking skills in processoriented task in ESL classroom. Procedia - Social and Behavioral Sciences, 171, 937-944. doi: 10.1016/j.sbspro.2015.01.212

Stapleton, P. (2001). Assessing critical thinking in the writing of Japanese university students: Insights about assumptions and content familiarity. Written Communication, 18(4), 506-548.

Vijayaratnam, P. (2012). Developing higher order thinking skills and team commitment via group problem solving: A bridge to the real world. Procedia-Social and Behavioral Sciences, 66, 53-63. doi: 0.1016/j.sbspro.2012.11.247.
Yang, L., \& Gao, S. (2013). Beliefs and practices of Chinese university teachers in EFL writing instruction. Language, Culture, and Curriculum. 26(2), 128-145. doi: 10.1080/07908318.2013.794817

Yen, T. S., \& Halili, S. H. (2015). Effective teaching of higher order thinking (HOTS) in education. The Online Journal of Distance Education and ELearning, 3(2), 41-47.

Zohar, A., \& Cohen, A. (2016). Large scale implementation of higher order thinking (HOTS) in civic education: The interplay of policy, politics, pedagogical leadership and detailed pedagogical planning. Thinking Skills and Creativity, 21, 85-96. doi: 10.1016/j.tsc.2016.05.003 